\title{
THE PAST AND FUTURE OF ENGLISH INSURANCE LAW: GOOD FAITH AND WARRANTIES
}

\author{
Peter MacDonald Eggers QC"
}

\begin{abstract}
This article reviews the current state of English insurance law applied to the duty of utmost good faith, in particular the assured's duty of full and accurate disclosure, and to insurance warranties, and examines the adequacy of the proposals made by the Law Commission for the reform of the law in both instances. Whilst recognising that there is a case for some reform, the reform recommended by the Law Commission is considered to extend beyond the bounds of what is necessary for the just and rational alteration of the law. In summary, the duty of utmost good faith requires no substantive reform as to the existence or scope of the duty, but does require a change by which the Courts will have the power to exercise a discretion to achieve a flexible remedial response to any breach of the duty. The principal reform which would benefit the law of warranties should concentrate on the clarity of the language in which the warranty is expressed and to identify the circumstances in which a true promissory warranty may be said to exist.
\end{abstract}

\section{A. INTRODUCTION}

Insurance contracts, and the body of law which has developed alongside the making and operation of such contracts, may be considered unique. Of course, they are a sub-species of contract and, it follows, that the English law of contract applies to insurance contracts. However, they have characteristics which no other contracts have. This is the inevitable result of the nature and effect of insurance contracts.

An insurance contract has been defined as a contract by which one party - the insurer - agrees to provide a benefit (usually, money) upon the occurrence of an uncertain event in consideration for the counterparty's the assured's - promise to pay a premium (usually, money). This is such a broad definition that it can encompass non-insurance transactions, in particular gaming or betting contracts. However, there are further features which serve to distinguish insurance contracts. There are in fact two types of insurance contract, a contract of contingency insurance or a contract of indemnity insurance. A contingency insurance contract is one by which the insurer undertakes to pay a sum of money on a stated contingency (the

\footnotetext{
*Barrister, 7 King's Bench Walk; Visiting Professor, University College London.
} 
insured peril), such as a specified sum on the death of or injury to the assured. However, it is not everyone who may insure a person's life; only those persons, such as relatives, who have a sufficient interest in the life insured may take out such insurance. This is the requirement of an insurable interest. By contrast, a betting transaction - for example, a bet that if a horse wins a race, the bettor will receive a specified sum of money - takes effect even if the person placing the bet has no interest in the subject matter of the bet.

An indemnity insurance contract is one by which the insurer promises to indemnify or compensate the assured for any loss suffered by reason of the uncertain event (the insured peril). The requirement that the assured suffer a loss is sufficient to mark an indemnity insurance contract from a betting contract. Nevertheless, in addition to the requirement of a loss, the law has also imposed a requirement of an insurable interest so that only those persons who have a sufficient interest in or relationship with the subject matter of the insurance may take out insurance in respect of that subject matter (such as a car under a motor insurance contract or a ship under a marine hull insurance policy).

Another way of characterising an insurance contract is to look at it as an agreement by which an insurer agrees to bear, in whole or in part, the risk of the uncertain event affecting the assured, which risk would normally be borne by the assured. Accordingly, by reason of such a contractual undertaking, the insurer voluntarily accepts that he or she will step into the shoes, or at least into one of the shoes, of the assured in specified circumstances. This is a remarkable feature, because most other contracts do not require this transference of risk unless it forms a natural consequence of the principal agreement between the parties. For example, if a person agrees to hire a motor vehicle or charter an ocean-going vessel from another person, there may be some circumstances where the hirer or charterer agrees to bear certain risks which would normally reside with the car- or ship-owner, but such agreements result from the hire or charter arrangement. The very essence of the insurance contract is that it involves this assignment of risk as the reason for the transaction.

Insurances are an inevitable feature of both domestic and commercial life. Most people with a capacity to contract will have entered into an insurance contract, even giving scant regard to the fact that such 
contracts have been concluded, when they have done so. For example, many people have benefited from or taken out life insurance, medical insurance, car insurance, travel insurance, and extended warranties over consumer products. Given the vast volume of insurance transactions, it is inevitable that the manner in which they are concluded are characterised by two near-universal features. First, when the assured and the insurer contract, the insurer is wholly reliant on the assured to provide information relating to the subject matter of the insurance or the circumstances of the assured to enable the insurer to evaluate the risk to be assigned or insured. Secondly, the insurer will include provisions in the insurance contract which are designed either to delineate the risks which the insurer is or is not prepared to accept or which are designed to impose obligations on the assured to provide information as to the nature of the risk and/or to take certain steps to ensure that the risks being insured are minimised.

It is these two characteristics which highlight two attributes of insurance contracts peculiar to such contracts and which have resulted in the evolution of a unique body of law. The two attributes are the parties' mutual duties of utmost good faith and the operation of insurance warranties in contracts of insurance. In many ways, these two attributes are essential to help protect the insurer's position considering that in many cases he is assuming responsibility for a risk otherwise borne by the assured on the faith and credit of the information and promises granted by the assured. Notwithstanding, these two attributes have developed in such a way that, where the assured lapses in the provision of information or in the promises he or she has made, there can be potentially harsh consequences for the assured as far as the protection otherwise afforded by the insurance contract is concerned. Such consequences may be harsh where in particular the assured has acted innocently or where the effect of such lapses is, as matters have turned out, trifling or minimal.

The potential harshness is such that over the past half-century, there has been a growing call by judges and legislators for law reform. The move towards law reform appears to be well underway, but it is by no means complete. This article is intended to consider the current state of the law and the current proposals for reform. 


\section{B. Three Pivotal Events}

English insurance law has a life of its own because insurance transactions are an endemic feature of everyday domestic and commercial life. As disputes invariably arise out of insurance transactions, because of the large number of such transactions, the Courts have had to develop and apply legal principles to each case. Parliament, however, has stepped in occasionally to clarify and change the law. The progress of insurance law in England is charted by three particular milestones, occurring in the latter part of the 18th century, at the beginning of the 20th century, and at the beginning of the 21 st century.

\section{Lord Mansfield}

English insurance law has been developing organically, generally at the hands of the Courts, for at least the past 250 years. In this sense, the law's evolution has responded to changing economic conditions, advancing technologies, and developing commercial practices and moral stances. The start of this judicial process represents the first significant step in the biography of English insurance law. Although insurance contracts had been in existence in Europe since the renaissance and had taken root in England in the 16th century, the law was for the first time bred, corralled, broken and trained by the organising intellect of Lord Mansfield, who was the Chief Justice of the King's Bench from 1756 to 1788 . He created a principled platform for the development of English insurance law, in particular for the duty of utmost good faith and warranties. ${ }^{1}$ Indeed, he has been described by Lord Eldon as 'the establisher, if not the author, of a great part of this law'. ${ }^{2}$ Indeed, in Lickbarrow v Mason (1787) 2 TR 63, Buller, J said (at page 73) that Lord Mansfield 'may be truly said to be the founder of the commercial law of this country'.

Thereafter, with Lord Mansfield's continuing influence, the common law of insurance constructed a clear, but harsh, edifice on this platform. ${ }^{3}$

\footnotetext{
${ }^{1}$ See e.g. Ross v Bradshaw (1761) 1 Black W 312 (good faith and warranty); Woolmer v Muilman (1763) 3 Burr 1418 (warranty); Hodgson v Richardson (1764) 1 Black W 463 (good faith); Carter v Boehm (1766) 3 Burr 1905 (good faith).

${ }^{2}$ Anderson v Pitcher (1800) 2 Bos \& Pul 164, 168.

${ }^{3}$ However, Edmund Burke said that Lord Mansfield 'sought to effect the amelioration of the law by making its liberality keep pace with justice and the actual concerns of the world ... confirming principles to the growth of commerce and our empire':
} 
It was easy to detect a punitive effect upon the assureds, because many assureds approached insurance contracts with little real understanding of the obligations upon them. On the other hand, there was a craving for legal certainty. The history of commercial law may be seen as the pitching of a balance between the two competing elements of fairness or justice on the one hand and certainty on the other. ${ }^{4}$ In Wardle $v$ Bethune (1871) LR 4 PC 33, the Privy Council said (at page 59): ${ }^{5}$

To use the language of Lord Mansfield as to a rule somewhat analogous, "At first the rule appears to be hard, but it is settled on principles of policy, and, when once established, every man contracts with reference to it, and there is no hardship at all."

\section{The Marine Insurance Act 1906}

As the 19th century drew to a close, a passionate longing for codification emerged. It is this drive towards a written, legislative statement of the law which brings about the second pivotal event in the history of English insurance law: Sir Mackenzie Chalmers's drafting of the Digest of Marine Insurance Law and the statute which became the Marine Insurance Act 1906.

The Marine Insurance Act 1906 was controversial when it was before Parliament as a bill. The bill had been drafted by Sir Mackenzie Chalmers, who was parliamentary counsel and later permanent undersecretary of state of the Home department. Throughout its life, the bill enjoyed the support of three successive Lord Chancellors. Despite 'mercantile opinion' in its favour, there were two waves of opposition to the bill, namely a political obstacle and opposition from the legal profession. At the turn of the 20th century, there was 'increasing difficulty in passing any measure of law reform' (reportedly on account

Report from the Committee to inspect the Lords Journals, in relation to the Proceedings on the Trial of Warren Hastings.

${ }^{4}$ It is not dissimilar to the competing principles of liberty and security in the philosophy of statecraft.

${ }^{5}$ Barclay v Y Gana (1784) 3 Dougl 390. 
of 'one obstinate member'). ${ }^{6}$ This political obstacle was finally negotiated under the guidance of Lord Loreburn. The second obstacle was the 'balance of legal opinion' against the bill. There was of course solid support for the measure. There were however numerous specific objections to the bill. There was also a larger objection rooted in principle: that the law of England should not be reduced to a written code. ${ }^{7}$ The support of the mercantile community was said to have rested in the certainty of a law which was simply laid out in an act of Parliament. The arguments marshalled against a codifying statute were twofold. First, codification would lead to ossification and the law could not be judicially developed to meet the justice of the case. Secondly, the bill would inevitably omit important exceptions or would include ambiguities.

In order to meet such opposition, Chalmers prepared a digest of the principles of marine insurance law (1901), comprising a series of general propositions of law based on the authorities, qualified by applicable exceptions and instantiated by a number of illustrations. Chalmers then exposed the digest to public review and criticism. Once the principles set out in the digest were revised to meet legitimate criticism, the terms of the digest could then be translated into the language of legislation. ${ }^{8}$ Chalmers was committed to the view that the legal objections could be reduced by careful draftsmanship, although he acknowledged that there were bound to be 'ambiguities and small discrepancies and obscurities ... which can only be cleared away by judicial interpretation."

The Marine Insurance Act 1906 is described as 'An Act to codify the Law relating to Marine Insurance'. Chalmers repeatedly emphasised that the legislation that he drafted was an exercise in codification, following the course of the 'wise lines laid down' by his mentor, Lord Herschell. In his 1901 Digest of Marine Insurance, Chalmers identified over 2,000 relevant authorities relating to marine insurance law. From

\footnotetext{
${ }^{6}$ See generally the introduction to Digest of the Law of Marine Insurance (1st edn, William Clowes and Sons Limited 1901); Mackenzie Chalmers, 'Codification of Mercantile Law' (1903) 19 LQR 10, 14.

${ }^{7}$ Alan Rodger, 'The Codification of Commercial Law in Victorian Britain' (1992) 108 LQR 570, 586-590.

${ }^{8}$ Chalmers, 'Codification of Mercantile Law' (n 6) 11-14.

${ }^{9}$ ibid 14-17.
} 
these authorities, Chalmers identified general principles of law. Codification was to be of benefit in the enunciation of general principles of law. ${ }^{10} \mathrm{~A}$ critical element of such codification is the use of concise and clear language. Indeed, it is on this last score that Chalmers can perhaps claim most credit. ${ }^{11}$ It is for this reason that Chalmers's views have remained influential in interpreting not only the 1906 Act but also the law of marine insurance so much so that any statements of principle in the Act are presumed to reflect the state of the law as it stood in $1906 .{ }^{12}$ Chalmers's influence is such that, in Pan Atlantic Insurance Co Ltd $v$ Pine Top Insurance Co Ltd [1995] 1 AC 501, a leading case on the duty of the utmost good faith, Lord Mustill said (at page 542) that 'Sir Mackenzie Chalmers was a most learned and careful scholar.'

It may be asked why the Marine Insurance Act 1906 is so important to the development of insurance law generally. It is because many principles of insurance law have developed from marine insurance law. Moreover, the principles relating to the duty of utmost good faith and warranties as set down in the 1906 Act have been held to be declaratory of the common law of non-marine insurance, as much as marine insurance. ${ }^{13}$

\section{The Law Commission Insurance Contract Project}

In 2006, the Law Commission issued a joint scoping paper designed to gauge professional and market opinion about the scope for reform of insurance contract law. As part of this project, the Law Commission has issued 9 Issues Papers and 3 Consultation Papers. ${ }^{14}$ The first Consultation Paper in July 2007 was concerned with the duty of utmost good faith (misrepresentation and non-disclosure) and warranties, both with respect

\footnotetext{
${ }^{10}$ Mackenzie Chalmers, 'An Experiment in Codification' (1886) 2 LQR 125.

${ }^{11}$ Soya GmbH v White [1982] 1 Lloyd's Rep 136, 144; Merkur Island Shipping Corp $v$ Laughton [1983] 2 AC 570, 594-595.

${ }^{12}$ Pan Atlantic Insurance Co Ltdv Pine Top Insurance Co Ltd [1995] 1 AC 501, 545, 570-571 (cf. 529-530); Raiffeisen Zentralbank Österreich AG v Five Star Trading LLC [2001] EWCA Civ 68; [2001] QB 825, [64]; The Mercandian Continent [2001] EWCA Civ 1275; [2001] 2 Lloyd's Rep 563, [21].

${ }^{13}$ Consultation Paper No. 204, paras. 2.2, 12.2.

${ }^{14}$ For the history of past efforts at the reform of the duty of utmost good faith, see Peter MacDonald Eggers, Simon Picken and Patrick Foss, Good Faith and Insurance Contracts ( $3^{\text {rd }}$ edn, 2010 Informa), ch. 5.
} 
to consumer insurance and business insurance. Following that Consultation Paper, it emerged that there was a wide-ranging consensus for the reform of consumer insurance law and a lack of consensus for the reform of business insurance law.

On 8th March 2012, following on the efforts of the Law Commission, Parliament enacted the Consumer Insurance (Disclosure and Representations) Act 2012. Although passed, the Act has not yet entered into force and cannot do so before 8th March 2013. This piece of legislation has fundamentally overhauled the duty of utmost good faith as it had previously applied to consumer insurance contracts. Once the Act becomes effective, the consumer assured will no longer be subject to a duty of disclosure and will be responsible for misrepresentations only where he or she has failed to exercise reasonable care, as judged by the standards of a reasonable consumer. Under the Act, the remedies available to the insurer will be depend on whether the assured acted fraudulently, recklessly or carelessly and on the effect of any misrepresentation on the judgment of the insurer.

The position with respect to business insurance contracts has been more complicated. On 26th June 2012, the Law Commission issued its third Consultation Paper (no. 204) principally dealing with the duty of disclosure (and also misrepresentation) as applied to business insurance contracts and warranties. ${ }^{15}$ The Law Commission envisages that it will issue a final report later in 2012, with a proposed bill to follow during 2013. The proposals put forward by the Law Commission in its June 2012 Consultation Paper are considered below.

\section{The Duty of Full and Accurate Disclosure}

\section{The Current Law}

The pre-contractual duty of disclosure is the most significant part of the duty of utmost good faith as applied in respect of insurance contracts. It was given its first extensive exposition by Lord Mansfield in Carter $v$ Boehm (1766) 3 Burr 1905. In that case, Lord Mansfield presiding at Guildhall over a disputed insurance claim held that the principle of good

\footnotetext{
${ }^{15}$ A second Consultation Paper relating to the post-contractual duties and other issues was published in December 2011 (Consultation Paper No. 201).
} 
faith applies to 'all contracts and dealings'. The duty of good faith embraced two distinct components when considered in the presentation of claims, namely the duty to make full disclosure of all material circumstances and the duty not to make material misrepresentations. The judgment given by the Lord Chief Justice was so influential that it can find its analogue directly in the statutory codification of the law drafted by Sir Mackenzie Chalmers in sections 18 and 20 of the Marine Insurance Act 1906.

There are in fact four sections of the statute which set out the law of the duty of the utmost good faith. Section 17 bears the marginal note or heading that 'Insurance is uberrimae fidei', in other words that insurance is of the utmost good faith. This is made explicit in the body of section 17 itself: 'A contract of marine insurance is a contract based upon the utmost good faith, and, if the utmost good faith be not observed by either party, the contract may be avoided by the other'. It has been queried whether the duty should be described as being of 'good faith' or of 'the utmost good faith'. ${ }^{16}$ The latter description is often viewed as arcane, apparently of some ancient origin. In truth, it is a neologism of the early 19th century. ${ }^{17}$ In should, however, be regarded as distinguishing the position applying to ordinary contracts, where the duty of good faith requires all parties to refrain from making misrepresentations. By contrast, the duty of utmost good faith requires not only an abstinence from stating untruths, but also the making of full disclosure. ${ }^{18}$

Section 18 sets out the assured's pre-contractual duty of disclosure in the following terms: ${ }^{19}$

The assured must disclose to the insurer, before the contract is concluded, every material circumstance which is known to the assured, and the assured is deemed to know every circumstance which, in the ordinary course of business, ought to be known by him.

\footnotetext{
${ }^{16}$ See also Consultation Paper No. 204, para. 10.24.

${ }^{17}$ In The Star Sea [2001] UKHL 1; [2003] 1 AC 469, [44], Lord Hobhouse said that the first recorded use of this term in 1850. However, the term was used earlier: see Williams v Rawlinson (1825) 3 Bing 71, 77; Morrison v Muspratt (1827) 4 Bing 60, 62 (in argument); Rothschild v Brookman (1831) 2 Dow \& Clark 188, 198; Cornfoot v Fowke (1840) $6 \mathrm{M} \& \mathrm{~W} 358,379$.

${ }^{18}$ Cf. Newton v Chorlton (1853) 10 Hare 646, 649.

${ }^{19}$ Sect. $18(1)$.
} 
The section proceeds to define what is material by reference to what would influence the judgment of a prudent insurer in deciding whether to enter into the insurance contract. ${ }^{20}$ There are specified in the provision 4 exceptions to the duty of disclosure, namely information (a) which diminishes the risk, (b) which is common knowledge or which is known or ought to be known to the insurer, (c) the disclosure of which has been waived by the insurer, and (d) the disclosure of which is superfluous by reason of the existence of a warranty in the policy. ${ }^{21}$

Section 19 sets out the duty of disclosure which applies personally to the assured's agent (the broker) in placing or entering into the insurance contract. Although the duty is borne by the agent, any failure to comply with the duty does not automatically give rise to a remedy against the agent by the insurer (in the absence of a cause of action in deceit or negligence). ${ }^{22}$ There is a further possible exception to the duty of disclosure identified in section 19, under sub-section (b), in that where the assured uses a broker to place the insurance, the assured and the broker may be excused from disclosing a material circumstance, where the information came to the assured's knowledge too late to communicate it to the broker.

Section 20 provides that any representation made by the assured to the insurer must be true or accurate. In particular, 'Every material representation made by the assured or his agent to the insurer during the negotiations for the contract, and before the contract is concluded, must be true'. The section defines materiality in a similar fashion to the definition adopted in section $18 .{ }^{23}$ Section 20 distinguishes between representations of fact on the one hand and representations of expectation or belief on the other hand. ${ }^{24} \mathrm{~A}$ representation of fact is treated as true where it is substantially true, in other words where the difference between what is represented and what is true is not regarded as material to a

\footnotetext{
${ }^{20}$ Sect. 18(2).

${ }^{21}$ Sect. 18(3).

${ }^{22}$ HIH Casualty and General Insurance Ltd v Chase Manhattan Bank [2000] 1 Lloyd's Rep 30, [100]-[105]; cf Pryke v Gibbs Hartley Cooper Ltd [1991] 1 Lloyd's Rep 602.

${ }^{23}$ Sect. 20(2).

${ }^{24}$ Sect. 20(3).
} 
prudent insurer. ${ }^{25}$ A representation of expectation and belief is true if it is made in good faith, that is honestly. ${ }^{26} \mathrm{~A}$ representation of expectation or belief is not regarded as untrue merely because the expectation is not fulfilled or the belief is not justified or correct. If, however, the expectation or belief as represented is not in fact entertained by the assured and is fraudulently represented, there will be a misrepresentation. ${ }^{27}$

There are similarities between establishing a breach of the duty of utmost good faith by non-disclosure on the one hand and by misrepresentation on the other hand, in particular the circumstances not disclosed or misrepresented must be 'material' in the sense that they 'would have been taken into account by the underwriter when assessing the risk'. ${ }^{28}$ This hypothetical underwriter concerned is an experienced, rational, ordinary, prudent, intelligent, fair and reasonable person in the position of the actual underwriter, ${ }^{29}$ and his judgment must be 'governed by the principles and calculations on which underwriters in practice act' ${ }^{30}$

No breach of the duty will be established, in the case of a nondisclosure or a misrepresentation, if the actual underwriter would not have been induced by the breach. In other words, if full and accurate disclosure had been made, and if the insurer would still have entered into the contract of insurance on the same terms, the insurer will have no remedy for the breach of the duty. On the other hand, if the insurer would

\footnotetext{
25 Sect. 20(4).

${ }^{26}$ Sect. 20(5).

${ }^{27}$ Economides v Commercial Union Assurance Co plc [1998] QB 587; Rendall v Combined Insurance Company of America [2005] EWHC 678 (Comm); [2006] 1 Lloyd's Rep IR 732, [103]; Kamidian v Holt [2008] EWHC 1483 (Comm); [2009] Lloyd's Rep IR 242, [85]-[94], 138-141. It is possible that the assured's expectation or belief is falsely represented by an innocent error: in such cases, there will be no misrepresentation: see Limit No. 2 Limited v AXA Versicherung $A G$ [2007] EWHC 2321 (Comm); [2008] Lloyd's Rep IR 330, [78]-[81]; [2008] EWCA Civ 1231; [2009] Lloyd's Rep IR 396, [22]-[28].

${ }^{28}$ Pan Atlantic Insurance Ltd v Pine Top Insurance Ltd [1995] 1 AC 501, 531, 538.

${ }^{29}$ Stribley v Imperial Marine Insurance Company (1876) 1 QBD 507, 514-515; Tate \& Sons v Hyslop (1885) 15 QBD 368, 377; Associated Oil Carriers Limited v Union Insurance Society of Canton Limited [1917] 2 KB 184.

${ }^{30}$ Ionides v Pender (1874) LR 9 QB 531, 539.
} 
not have entered into the contract at all, or would have entered into the contract only on different terms (for example, subject to additional exclusions or at a different premium), the insurer will have been induced by the non-disclosure or misrepresentation and there will have been an actionable breach of the duty of utmost good faith. ${ }^{31}$

The differences between the test of materiality and the requirement of inducement are that in the former case the judgment of the prudent, hypothetical underwriter is in issue and the impact on that judgment is a relatively low threshold in that it need only be a matter which would enter into the prudent underwriter's calculations, and no decisive impact need be proved..$^{32}$ In the latter case it is the judgment of the actual underwriter which matters and the impact on his or her judgment must be decisive.

A critical element of establishing a material non-disclosure in breach of the duty of utmost good faith is that the assured must have the requisite degree of actual or deemed knowledge of the material circumstance. ${ }^{33}$ There is no requirement of knowledge in order to establish a breach of duty by misrepresentation in that the representation must be untrue, whether or not it was known to be untrue.

In each case, there will be a breach of the duty of the utmost good faith whether or not the assured acted fraudulently, negligently or entirely without blame. ${ }^{34}$ Sections 17,18 and 20 all state that the remedy for a breach of the duty of the utmost good faith is the avoidance of the insurance contract (with the consequent restitutionary remedies which would arise upon a valid avoidance). The Courts have not allowed any other remedy, in particular damages, for any breach of the duty of the

\footnotetext{
${ }^{31}$ Pan Atlantic Insurance Ltd v Pine Top Insurance Ltd [1995] 1 AC 501; Assicurazioni Generali SpA v Arab Insurance Group (BSC) [2002] EWCA Civ 1642; [2003] Lloyd's Rep IR 131, [62], [78], [215]-[221]; Sugar Hut Group Ltd v Great Lakes Reinsurance (UK) plc [2010] EWHC 2636 (Comm); [2011] Lloyd's Rep IR 198, [23]-[25].

${ }^{32}$ Pan Atlantic Insurance Ltd v Pine Top Insurance Ltd [1995] 1 AC 501, 531.

${ }^{33}$ It is also well arguable that an assured will have imputed to him or her the knowledge of a relevant agent by the law of agency. However, note Group Josi Reinsurance Co Ltd v Walbrook Insurance Co Ltd [1996] 1 Lloyd's Rep 345, 365366.

${ }^{34}$ Whitlam v Hazel [2004] EWCA Civ 1600; [2005] Lloyd's Rep IR 168.
} 
utmost good faith, principally because no other remedy is specified in sections $17-20$ of the 1906 Act. $^{35}$

Section 17 states the general duty of the utmost good faith. Sections 18-20 make detailed provision for the duty, but only in respect of the assured's duty of full and accurate pre-contractual disclosure. However, in his Marine Insurance Act 1906 (2nd ed., 1913), Sir Mackenzie Chalmers made it clear that the provisions of sections 18-20 were not exhaustive. ${ }^{36}$ The Marine Insurance Act 1906 is therefore silent in two respects. First, no specific provision - other than the general reference in section 17 - is made for the insurer's duty of utmost good faith. It is plain that section 17 imposes a duty upon both the assured and the insurer in that it provides that '.. . if the utmost good faith be not observed by either party, the contract may be avoided by the other' (emphasis added). In other words, the duty is mutual or reciprocal, binding both the assured and the insurer. ${ }^{37}$ However, in most cases, as the assured comes to the insurance transaction in possession of most of the information and the insurer has comparatively little knowledge of the risk, the duty will be borne by the assured more onerously. ${ }^{38}$

${ }^{35}$ Banque Keyser Ullmann SA v Skandia (UK) Insurance Co Ltd [1990] 1 QB 665; [1991] 2 AC 249, 274; The Good Luck [1989] 2 Lloyd's Rep 238, 263. However, damages may be available on other grounds, e.g. in deceit, for breach of a common law duty of care, or under the Misrepresentation Act 1967.

${ }^{36}$ The Star Sea [2001] UKHL 1; [2001] 2 WLR 170, [48].

${ }^{37}$ Carter v Boehm (1766) 3 Burr 1905, 1909-1910; Britton v Royal Insurance Company (1866) 4 F\&F 905, 909 ('on both sides'); Banque Financière de la Citév Westgate Insurance Co Ltd [1990] 2 All ER 947, 960; Pan Atlantic Insurance Co Ltd v Pine Top Insurance Co Ltd [1994] 2 Lloyd's Rep 427, 456; The Star Sea [2001] UKHL 1; [2003] 1 AC 469, [47]; James Park, A System of the Law of Marine Insurances (8th edn, Saunders and Benning 1842), 403. See in the context of the pre-contractual duty, Aldrich v Norwich Union Life Insurance Co Ltd [2000] Lloyd's Rep IR 1.

${ }^{38}$ Anderson v Pacific Fire and Marine Insurance Company (1872) LR 7 CP 65, 68; Greenhill v Federal Insurance Co Ltd [1927] 1 KB 65, 76; Banque Financière de la Cite'v Westgate Insurance Co Ltd [1989] 2 All ER 952, 988; Pan Atlantic Insurance Co Ltd v Pine Top Insurance Co Ltd [1994] 2 Lloyd's Rep 427, 447, 456; Société Anonyme d'Intermédiaires Luxembourgeois v Farex Gie [1995] LRLR 116, 149. Indeed, it has been suggested that this imbalance in the parties' knowledge, coupled with the duty of disclosure, puts the assured in a weaker 
Secondly, no provision is made for the post-contractual duty of utmost good faith. Since the late 19th century, it has been assumed that the duty of utmost good faith applied after the contract was concluded. It has been recognised that the pre-contractual duty revives when the insurer has to exercise underwriting judgment, for example where the contract of insurance is varied or amended. ${ }^{39}$ However, even in the absence of such cases, it was long considered that the duty of utmost good faith applied to the performance of the contract, as much as to the conclusion of the contract, particularly over the past 20 years. ${ }^{40}$ The difficulty is that section 17 of the 1906 Act does not explicitly state that the duty of utmost good faith continues beyond the making of the insurance contract and further does not define the scope of that duty. In The Mercandian Continent [2001] EWCA Civ 1275; [2001] 2 Lloyd's Rep 563, Longmore, LJ said (at paragraph 22(8)) that the draftsman of the Act plainly intended that the duty applied after the contract was made.

In The Star Sea [2001] UKHL 1; [2001] 2 WLR 170, the House of Lords was in fact reluctant to extend the duty of utmost good faith to include post-contractual fraud, ${ }^{41}$ but acknowledged that such a conclusion was, in 2001, inevitable. In this case, the House of Lords held that any post-contractual duty was limited to a duty to abstain from acting fraudulently. Lord Hobhouse's judgment has been read as extending an invitation to the Courts to find a way around the statutory remedy of avoidance for post-contractual fraud. Mance, LJ in Agapitos $v$ Agnew [2002] EWCA Civ 247; [2002] 2 Lloyd's Rep 42, at paragraph 13,

position: R.A. Hasson, 'The Doctrine of Uberrima Fides in Insurance Law - A Critical Evaluation' (1969) 32 MLR 615, 633-634.

${ }^{39}$ The Mercandian Continent [2001] EWCA Civ 1275; [2001] 2 Lloyd's Rep 563, [22].

${ }^{40}$ The Good Luck [1990] 1 QB 818, 888; Bucks Printing Press Ltd v Prudential Assurance Co [1994] 3 Re LR 219, 223; New Hampshire Insurance Company v MGN Ltd [1997] LRLR 24, 48; Orakpo v Barclays Insurance Services [1995] LRLR 443, 451, 452; Royal Boskalis Westminster NV v Mountain [1997] LRLR 523, 592, 600; Galloway v Guardian Royal Exchange (UK) Ltd [1999] Lloyd's Rep IR 209, 212-214, 214. See also D.R. Thomas, 'Fraudulent Insurance Claims: Definition, Consequences and Limitations' [2006] LMCLQ 485, 512.

${ }^{41}$ [6], [48], [72]; cf. [106]. See also Howard Bennett, 'Mapping the doctrine of utmost good faith in insurance contract law' [1999] LMCLQ 165; Bariş Soyer, 'Continuing duty of utmost good faith in insurance contracts: still alive?' [2003] LMCLQ 45. 
appealed to Parliament and the House of Lords to limit the duty of good faith to the pre-contract stage. It nevertheless appears to be well established that the duty of utmost good faith has a post-contractual element. In The Mercandian Continent, ${ }^{42}$ Longmore, LJ did not consider that it was open to the Court of Appeal to reach a different decision on the continuing nature of the duty. This decision therefore confirms that after the conclusion of the insurance contract, the parties owe each other a duty not to be fraudulent in their performance of the contract or in their dealings in connection with the contract.

\section{The Law Commission's Proposals}

In its recent Consultation Paper no. 204, published on 26th June 2012, the Law Commission has focussed only on the assured's, and not the insurer's, pre-contractual duty of disclosure and has made limited suggestions with respect to the law relating to misrepresentation inducing the conclusion of an insurance contract. The Law Commission already addressed the assured's post-contractual duty (in particular, in respect of claims) in its Consultation Paper no. 201 published in December 2011. This article will concentrate on the proposals made in Consultation Paper no. 204.

In its recent Consultation Paper, the Law Commission identified a number of reasons which necessitate reform of the law. The Law Commission believes that the duty of disclosure contributes to difficulties perceived in the marketplace in the following ways: ${ }^{43}$

1. Policyholders do not understand the duty at least insofar as they find it difficult to know what information the insurer requires to be disclosed. The fact that many business assureds are being advised by brokers - who it might be thought could provide professional advice to the business assured as to the type of information required to be disclosed - offers no solution, especially where brokers' incomes have recently reduced, because 'Brokers have therefore less time to devote to visiting and understanding the client's business'. ${ }^{4}$

\footnotetext{
${ }^{42}$ [2001] EWCA Civ 1275; [2001] 2 Lloyd's Rep 563, [34], [39]-[40].

${ }^{43}$ Consultation Paper No. 204, para. 4.53.

${ }^{44}$ ibid para. 4.39 .
} 
2. It is unclear whose knowledge within a large organisation is relevant to that organisation's duty of disclosure.

3. Insurers have insufficient incentive to ask questions when underwriting the risk.

4. The remedy for non-disclosure is unduly harsh.

With these considerations in mind, the Law Commission has put forward its proposals for law reform.

\section{(a) Materiality}

The Law Commission recommends that the duty of disclosure set out in section 18(1) of the Marine Insurance Act 1906 be retained, but that the concept of materiality should be clarified in legislation and that the legislation should specify that (a) a material circumstance is a circumstance required to provide a fair presentation of the risk and that (b) a fair presentation should include (i) the disclosure of any unusual or special circumstances which increase the risk, (ii) any particular concerns about the risk which led the assured to seek the insurance, and (iii) standard information which market participants generally understand should be disclosed. ${ }^{45}$

One of the legitimate concerns with the current statutory test of materiality is that it is based on the judgment of a reasonable person in the position of the insurer and that the assured, who bears the brunt of the duty of disclosure, is in the difficult position of trying to assess what a reasonable person, not in the position of the assured, but in the position of the insurer, would want disclosed. In reaction to this test, it had been suggested in the past that a 'reasonable insured' test of materiality should be introduced. However, the Law Commission correctly refers to the uncertainties created by this test, because the large variety of assureds bearing in mind that assureds vary by reference to size, nationality, business and governance - would necessarily result in varying boundaries of the what would be regarded as material. ${ }^{46}$

\footnotetext{
${ }^{45}$ Consultation Paper No. 204, para. 5.72.

${ }^{46}$ ibid para. 4.64-4.71.
} 
The same concern would apply to any test of materiality which defines the scope of the insurer's pre-contractual duty of disclosure. ${ }^{47}$ Any test of materiality of information for disclosure by one party by reference to the position of the other party will pose difficulties for the former of foreshadowing what a reasonable person in the position of the latter would want to take into account in determining whether or not to enter into the contract.

When expert witnesses give evidence at trial on what information a prudent insurer would consider as material, the debate is framed by reference to what information would objectively and rationally relate to the risk being assumed by the insurer. The test of a prudent insurer or a reasonable assured can be dispensed with in favour of a simpler test based on objective relevance of the information to the risk. In fact, there is authority to indicate that such a test applies, as matters stand, in addition to the prudent insurer test. ${ }^{48}$ Such a test has the benefit of being simple to apply and of being concerned only with the risk associated with the insurance transaction. For this purpose, 'risk' does not refer only to the risk of an insured peril or loss or damage occurring, but instead the risk of financial loss to the insurer under the transaction, thus allowing information relating to subrogation to be taken into account. ${ }^{49}$

The Law Commission's proposals at first sight appear insufficient because the general requirement that materiality be tested in light of what is required for the purposes of a 'fair presentation of the risk' merely redefines materiality by a generalist abstraction. Further, the test of 'fair presentation' in the past has been used to explain the relationship between the duty of full disclosure interacting with the exception to the duty which arises where the assured provides a summary and puts the insurer

\footnotetext{
${ }^{47}$ As to the test of materiality applicable to the insurer's duty of disclosure, see Banque Keyser Ullmann SA v Skandia (UK) Insurance Co Ltd [1990] 1 QB 665, 772; [1991] 2 AC 249, 268, 281-282.

${ }^{48}$ Glasgow Assurance Corp Ltd v Symondson \& Co (1911) 16 Com Cas 109, 119120; Société Anonyme d'Intermediaries Luxembourgeois v Farex Gie [1995] 2 Lloyd's Rep 116, 149; O'Kane v Jones [2003] EWHC 2158 (Comm); [2004] 1 Lloyd's Rep 389, [222]. See also Permanent Trustee Australia Ltd v FAI General Insurance Co Ltd [2003] HCA 25; (2003) 77 ALJR 1070, [32]-[33].

${ }^{49}$ Société Anonyme d'Intermediaries Luxembourgeois v Farex Gie [1995] 2 Lloyd's Rep 116, 149.
} 
on inquiry of the existence of further information so that any failure on the part of the insurer to require further disclosure results in a waiver of such disclosure. ${ }^{50}$ The Law Commission also proposes that the law relating to waiver as currently understood by section 18 should be left as it is. $^{51}$

The Law Commission's proposals then proceed to limit the material information to be disclosed by reference to information which 'increases' the risk, without defining what the 'risk' entails, and ignores information which may not increase the risk, but merely impinges on the nature or character of the risk. Of course, under the current law, any information which diminishes the risk need not be disclosed. The other two categories of information which the Law Commission suggests should be included in the duty of disclosure may be too limiting or may include information which may not be truly material or relevant. Information relating to the assured's concerns may or may not bear objectively on the risk and information based on market understandings requires input of expert evidence and is open-ended in its nature (as the Law Commission recognises)..$^{52}$

Overall, the Law Commission's recommendations will achieve less certainty than the current law and may in fact operate too artificially to provide any real assistance in defining the scope of the duty of disclosure which the Law Commission accepts should be retained as part of the law.

\section{(b) The Assured's Knowledge}

The Law Commission's proposals in respect of the knowledge component of the assured's duty of disclosure appear to be no more than a 'restatement of the law'. ${ }^{53}$ To this end, its recommendations focus on two aspects of knowledge: (a) who possesses the relevant knowledge requiring disclosure, and (b) what type of knowledge is relevant. These are both important questions, because either the law itself is not entirely

\footnotetext{
${ }^{50}$ The Dora [1989] 1 Lloyd's Rep 69, 88-89; Simner v New India Assurance Co Ltd [1995] LRLR 240, 252; Newbury International Ltd v Reliance National Insurance Co (UK) Ltd [1994] 1 Lloyd's Rep 83, 90; Svenska Handelsbanken v Sun Alliance and London Insurance plc [1996] 1 Lloyd's Rep 519, 567.

${ }^{51}$ Consultation Paper No. 204, para. 5.76-5.77.

52 ibid para. 5.73-5.75.

${ }^{53}$ ibid para. 6.73 .
} 
clear or because the application of law to the facts in an individual case may give rise to uncertainty. Although a restatement will assist on the former question, it will not assist on the latter. However, the restatement proposed by the Law Commission on the former question is no more than an inclusive test, thus leaving much which falls outside the restatement uncertain.

The Law Commission proposes that the persons who should have the relevant knowledge should include the directing mind and will of an organisation, where the assured is other than an individual, and the persons who arranged the insurance on behalf of the organisation. This restatement however provides little assistance, because it is already clear that circumstances known to the directing mind and will, the placing broker, and those within the insured organisation who arranged the insurance, should be disclosed. ${ }^{54}$ Indeed, section 19 of the Marine Insurance Act 1906 imposes a personal duty of disclosure on the placing broker, although it has been held that this statutory duty does not extend to a producing or intermediate broker or a former broker of the assured. ${ }^{55}$ The Law Commission makes a specific proposal for including within the relevant class of persons who bears a duty of disclosure under section 19 not only the placing broker but also the producing or intermediate broker. ${ }^{56}$ Furthermore, the broker's knowledge is limited to that information held by the broker in his or her capacity as the assured's agent and does not extend to information which is held by the broker as

${ }^{54}$ Group Josi Reinsurance Co Ltd v Walbrook Insurance Co Ltd [1996] 1 Lloyd's Rep 345, 366-367; Société Anonyme d'Intermediaries Luxembourgeois v Farex Gie [1995] 2 Lloyd's Rep 116, 143, 150, 157.

${ }^{55}$ Blackburn Low \& Co v Vigors (1887) 12 App Cas 531; PCW Syndicates v PCW Reinsurers [1996] 1 Lloyd's Rep 241, 258-259.

${ }^{56}$ Consultation Paper No. 204, para. 7.73. The Law Commission has raised the question whether the exception in sect. 19(b) of the Marine Insurance Act 1906 should be retained (para. 7.77) suggesting that it is 'redundant'. However, that provision does include an exception to the duty of disclosure where the assured is possessed of material information prior to the time when the insurance contract is concluded, but which the assured is unable to communicate to the broker prior to the placing of the insurance. 
the agent of another person. ${ }^{57}$ The Law Commission has proposed that this position should continue.

However, it is also clear that other persons' knowledge will be relevant for the purposes of disclosure, including the knowledge of the assured's general agents and those agents or employees who are responsible for the general care and custody of the subject-matter of the insurance (such as the master of a ship or the general manager of a factory). ${ }^{58}$

The Law Commission also states that the types of knowledge possessed by the assured which will define the scope of the duty of disclosure will be the assured's actual knowledge, which would include 'blind eye' knowledge - that is where the assured would become aware of a fact had he or she not wilfully shut his or her eyes to the fact ${ }^{59}$ - and 'information that would have been discovered by reasonable enquiries, which are proportionate to the type of insurance and to the size, nature and complexity of the business'. ${ }^{60}$ There can be no dispute that actual knowledge, including blind-eye knowledge, is relevant to the assured's duty of disclosure, although actual knowledge must be such which is in the mind of the assured at the time of making the insurance contract.

The difficulty with the 'reasonable enquiries' test is that on its face it may have the effect of expanding the knowledge deemed to be possessed by the assured. The current formulation of deemed knowledge under section 18(1) of the Marine Insurance Act 1906 is that '...the assured is deemed to know every circumstance which, in the ordinary course of business, ought to be known by him...'. The phrase 'in the ordinary course of business' has been defined by reference to the actual manner in which the assured conducts its business, rather than the ordinary course of business as would be conducted by a reasonable person in the

${ }^{57}$ Société Anonyme d'Intermediaries Luxembourgeois v Farex Gie [1995] 2 Lloyd's Rep 116, 143, 150, 157; Group Josi Reinsurance Co Ltd v Walbrook Insurance Co Ltd [1996] 1 Lloyd's Rep 345, 361, 367.

${ }^{58}$ Blackburn Low \& Co v Vigors (1887) 12 App Cas 531; Simner v New India Assurance Co Ltd [1995] LRLR 240, 254-255.

${ }^{59}$ Economides v Commercial Union Assurance Co plc [1998] QB 587, 601-602, 607.

${ }^{60}$ Consultation Paper No. 204, para. 6.75-6.78. 
assured's position. ${ }^{61}$ The test put forward by the Law Commission may well impose a more stringent requirement on the assured to make reasonable enquiries, at least where reasonableness is assessed by reference to the industry as a whole, although the Law Commission notes that the 'test should accept that not all companies are perfectly run'. ${ }^{62}$

The open issue however which is not considered by the Law Commission, and which requires attention, is whether the knowledge of an agent is automatically to be imputed to the assured pursuant to the law of agency or whether such knowledge can be attributed only if it would have been communicated to the assured in the ordinary course of business. $^{63}$

\section{(c) The Insurer's Knowledge}

The Law Commission also focuses on the boundaries of the insurer's knowledge insofar as it constitutes an exception to the assured's duty of pre-contractual disclosure as set out in section 18(3)(b) of the Marine Insurance Act $1906 .{ }^{64}$ In this respect, the Law Commission does not propose any alterations to the current state of the law. For example, it states that matters of actual, common or deemed knowledge should be included in this exception. The most difficult aspect of this exception is the insurer's deemed knowledge, knowledge which a well-informed underwriter ought to have. In this respect, the Law Commission refers to matters which the insurer ought to have based on the practices and risks of the insured trade. This however is already plainly encompassed in the current formulation of the exception ('matters which an insurer in the ordinary course of his business, as such, ought to know') which includes

${ }^{61}$ Australia \& New Zealand Bank v Colonial \& Eagle Wharves Ltd [1960] 2 Lloyd's Rep 241, 252; Simner v New India Assurance Co Ltd [1995] LRLR 240, 253-255; ERC Frankona Reinsurance v American National Insurance Co [2005] EWHC 1381 (Comm); [2006] 1 Lloyd's Rep IR 157, [173].

${ }^{62}$ Consultation Paper No. 204, para. 6.77.

${ }^{63}$ In Group Josi Reinsurance Co Ltd v Walbrook Insurance Co Ltd [1996] 1 Lloyd's Rep 345, 365-366, the Court of Appeal held that it was so limited. However, this ignores the law of agency.

${ }^{64}$ Consultation Paper No. 204, para. 8.42-8.50. 
the 'normal risks' associated with the insured activity, but not 'unusual risks. ${ }^{65}$

In addition, the Law Commission states that information held by the insurer's agent or employee which ought to have been communicated to the underwriter should form part of the exception. This is problematic. The Law Commission recognises that the knowledge relevant to this exception is the knowledge held by the underwriter - the person making the underwriting decision - and the directing mind and will of the insurer (insofar as the insurer is not an individual). However, the real question is the extent to which information held by large corporate insurers should be treated as falling within the exception. For example, the question arises whether the exception extends to information which is not actually known to the underwriter but which is known to (a) members of the underwriter's team, (b) other employees of the underwriter's department, (c) employees of other, but closely associated, departments, (d) employees of other, more distant departments (e.g. those departments which are located in different cities), and (e) external databases or agencies whom the underwriter could consult. At present, although this may be disputed, it appears that the law does not require the assured to disclose information which could be retrieved by the insurer if the insurer complied with that particular insurer's usual business practices. ${ }^{66}$ If, for example, the insurer upon receiving a proposal for a risk would as a matter of that insurer's usual course of business check a particular internal or external computer database, any information which would have been retrieved upon such a search would be deemed to be known to the insurer, whether or not the insurer in fact undertook that search.

The danger with the Law Commission's current proposals is that it seeks to restate the law in terms different to the current statutory language, which has benefited from a continuing process of judicial interpretation, which construction might be dispensed with if the language of the statute were to change. There can be value in such a

\footnotetext{
${ }^{65}$ North British Fishing Boat Insurance Co Ltd v Starr (1922) 13 Ll L Rep 206, 210; Greenhill v Federal Insurance Co Ltd [1927] $1 \mathrm{~KB} 65$; Marc Rich \& Co AG v Portman [1996] 1 Lloyd's Rep 430, 442; aff'd [1997] 1 Lloyd's Rep 225.

${ }^{66}$ Bates v Hewitt (1867) LR 2 QB 595; London General Insurance Company v General Marine Underwriters' Association [1921] 1 KB 104, 111, 112; Malhi v Abbey Life Assurance Co Ltd [1996] LRLR 237.
} 
statutory exercise only if it were intended to alter the law or clarify a genuinely uncertain area of the law. None of the Law Commission's proposals appear to achieve this object.

\section{(d) Knowledge and Misrepresentation}

Finally, on the question of knowledge, the Law Commission has proposed that the same requirements of knowledge should be applied to both section 18 (non-disclosure) and section 20 (misrepresentation) of the Marine Insurance Act $1906 .{ }^{67}$ This is a difficult recommendation to understand. There is no requirement of knowledge in order to prove a misrepresentation, except possibly in one limited context. There is a distinction drawn in section 20 between representations of fact (which can constitute a breach of the duty of utmost good faith whether the representation was or was not known to be untrue) and representations of expectation and belief which are deemed to be untrue only if they are made fraudulently - in this sense, they have a requirement of knowledge in that they are untrue only if the assured knows that the representation of expectation or belief - i.e. of the assured's state of mind which the assured is in a unique position to assess - is untrue.

The Law Commission's desire to apply a requirement of knowledge to these two distinct kinds of breach is based on an apparent misconception. The relevance of knowledge to an actionable nondisclosure and to an actionable misrepresentation is in fact different. In the former case, it is the knowledge - actual or deemed knowledge - of the material circumstance which gives rise to the duty of disclosure. ${ }^{68} \mathrm{In}$ the latter case of a misrepresentation, the assured's knowledge is technically irrelevant. It is certainly irrelevant to the case of a misrepresentation of fact. If the assured's representation is material and induces the insurer to enter into the insurance contract, it will permit the insurer to avoid the contract. Whether or not the assured is aware or ought to be aware that the representation is false is irrelevant to the insurer's entitlement to avoid. The position is the same with respect to the ordinary law of misrepresentation in that any innocent misrepresentation gives rise to an equitable right on the part of the representee to rescind the

\footnotetext{
${ }^{67}$ Consultation Paper No. 204, para. 6.91-6.95.

${ }^{68}$ Joel $v$ Law Union and Crown Insurance Company [1908] 2 KB 863, 884-885.
} 
contract induced by the misrepresentation. If the Law Commission's proposals were carried forward, it would create a sizeable gulf between the law applicable to insurance contracts and the law applicable to ordinary contracts, without any sensible grounds for the distinction.

Furthermore, the association of the concept of knowledge to a misrepresentation of an expectation or belief is to ignore the real nature of such a misrepresentation. Knowledge becomes important in this respect because the representation made by the assured is not of an objectively determinable external fact, but of the state of the assured's mind, and such a representation must necessarily be associated with the assured's state of knowledge, not because it is implicit in the elements of an actionable misrepresentation but because it is inherent in the nature of the representation; in other words, the representation is as to what the assured expects or believes. ${ }^{69}$

\section{(e) Remedies}

The area of the law deserving the greatest measure of criticism concerns the remedies available for a breach of the duty of the utmost good faith. In fact, it is the remedy, not the duty itself, which requires reform. The Marine Insurance Act 1906 identifies only one remedy, namely that of avoidance. The Court of Appeal has construed the statute as excluding all other possible remedies, in particular damages. ${ }^{70}$ This has caused a real difficulty and a genuine injustice in that: ${ }^{71}$

1. In most cases, the party in breach will be the assured, not the insurer. The remedy is essentially one-sided.

\footnotetext{
${ }^{69}$ Representations of opinion are treated in the same way as representations of expectation and belief: Economides v Commercial Union Assurance Co plc [1998] QB 587. Oddly, it has been held that a representation of intention is not such a representation (St Paul Fire \& Marine Insurance Co (UK) Ltd v McConnell Dowell Constructors Ltd [1995] 2 Lloyd's Rep 116, 127; Limit No. 2 Limited v AXA Versicherung $A G$ [2007] EWHC 2321 (Comm); [2008] Lloyd's Rep IR 330, [46]; [2008] EWCA Civ 1231; [2009] Lloyd's Rep IR 396, [17]-[18]).

${ }^{70}$ Banque Keyser Ullmann SA v Skandia (UK) Insurance Co Ltd [1990] 1 QB 665; [1991] 2 AC 249, 274; The Good Luck [1989] 2 Lloyd's Rep 238, 263.

${ }^{71}$ The Star Sea [2001] UKHL 1; [2003] 1 AC 469, [57]; D.R. Thomas (ed.), Marine Insurance: The Law in Transition (Informa 2006), para. 3.40-3.50.
} 
2. Avoidance is an 'all or nothing' remedy so that the insurer has no choice, in the face of a breach, but to avoid or to affirm the insurance contract.

3. Avoidance is seldom a desirable remedy from the assured's perspective in that the assured will in most, but not all, cases wish to maintain rather than set aside the insurance contract.

4. The remedy is available for all breaches, irrespective of the magnitude of the breach, the distorting effect on the insurer's assessment of the risk as presented, and the blameworthiness of the assured's breach.

Accordingly, there is a palpable flaw in the law, as enshrined by statute and judicial construction of that statute, which requires attention by the legislature. Recent judicial unease with the state of the law has induced the Courts to temper the remedies available for a breach of the postcontractual duty, ${ }^{72}$ recognising that reforming the remedies for a breach of the pre-contractual duty is beyond the power of the Courts.

The Law Commission has, by its proposals, sought to tailor the remedy of avoidance to operate as both a punitive provision (in the case of fraud) and a qualified compensation provision. It proposes that (a) if the assured has acted fraudulently in not making full and accurate disclosure, the insurer may avoid the contract and retain the premium, (b) if the assured has acted other than fraudulently, and (i) if the insurer would not have entered into the contract at all had full and accurate disclosure been made, the insurer may avoid the contract, (ii) if the insurer would not have entered into the contract on the same terms (other than as to premium) had full and accurate disclosure been made, the contract is to be treated as if it included those terms, and (iii) if the insurer would have entered into the contract on the same terms but at a higher premium had full and accurate disclosure been made, the amount

\footnotetext{
${ }^{72}$ Agapitos v Agnew (The Aegeon) [2002] EWCA Civ 247; [2002] 2 Lloyd's Rep 42; Axa General Insurance Ltd v Gottlieb [2005] EWCA Civ 112; [2005] Lloyd's Rep IR 369. The first case dealt with the issue of forfeiture and avoidance obiter; the second case was a case where the insurer did not seek to avoid the insurance contract.
} 
to be paid on a claim under the insurance contract is to be reduced proportionately, and (c) where the insurer is entitled to apply such remedies, the insurer should be entitled to cancel the insurance contract for the future. ${ }^{73}$

These proposals are plainly well considered and are defensible in any rational discussion. They are not, however, immune from criticism. First, there is no provision for a discretion which takes account of all relevant circumstances. For example, a minor breach of the duty may be fraudulently motivated but have a relatively inconsequential effect on the insurer's decision-making. On the other hand, a very serious lapse in disclosure may distort the risk substantially even though the breach was inadvertent. The Courts are able to exercise a discretion under the Misrepresentation Act 1967 at least where the misrepresentation is nonfraudulent. ${ }^{74}$ Secondly, compensation provisions are well and good, but they ignore the fact that the insurer's consent to the insurance contract was vitiated by the non-disclosure or misrepresentation and avoidance is the orthodox and appropriate remedy in all non-insurance cases at least where there has been a misrepresentation. If it were thought that there may be cases where compensation will achieve the desired end, the Courts exercise a relevant discretion to override the avoidance and substitute a damages remedy (as is the case under the Misrepresentation Act 1967). Thirdly, a right of cancellation will seldom be useful in that in most cases the breach of the duty of utmost good faith will be discovered only after the insurance contract has run its course, at which point cancellation will provide little assistance.

Notwithstanding such criticisms, the current proposals make sense, but they do not go far enough to cater for all potential injustices and to ensure consistency with the ordinary law of misrepresentation.

\footnotetext{
${ }^{73}$ Consultation Paper No. 204, para. 9.28-9.40, 9.60-9.62, 9.63-9.76.

${ }^{74}$ In Highlands Insurance Co v Continental Insurance Co [1987] 1 Lloyd's Rep 109, 117-118, Steyn, J held that the Courts should not exercise any discretion under the 1967 Act to disallow avoidance for breach of the duty of utmost good faith. See also HIH Casualty and General Insurance Ltd v Chase Manhattan Bank [2001] EWCA Civ 1250; [2001] 2 Lloyd's Rep 483, [51], [116].
} 


\section{WARRANTIES}

\section{The Current Law}

Insurance warranties are different from terms found in ordinary contracts not as regards the nature of the promise encompassed by the warranty but as regards the consequences of a breach of the warranty. Under an ordinary contract, a breach of a contractual term will either result in the innocent party being entitled to terminate the contract prospectively (if the breach is sufficiently serious) and/or to claim damages for losses caused by the breach.

Breaches of a promissory warranty under an insurance contract result in the automatic discharge of the insurer from liability, because the warranty is relevant to the nature and scope of the risk which the insurer has agreed to bear by reason of the insurance transaction. The law of insurance warranties is set out in sections 33-35 of the Marine Insurance Act 1906 which are generally regarded as declaring the law applicable to non-marine insurance contracts as well as marine insurance contracts. ${ }^{75}$ Section 33(1) of the Marine Insurance Act 1906 defines a warranty as:

a promissory warranty, that is to say, a warranty by which the assured undertakes that some particular thing shall or shall not be done, or that some condition shall be fulfilled, or whereby he affirms or negatives the existence of a particular state of facts.

Warranties may be express or implied. Under section 35(1), an 'express warranty may be in any form of words from which the intention to warrant is to be inferred'. Under section 35(2), an 'express warranty must be included in, or written upon, the policy, or must be contained in some document incorporated by reference into the policy.' It is therefore essential that an express warranty be included or written upon the policy or incorporated by a reference in the policy. The warranty or reference may be found anywhere in writing in the policy. ${ }^{76}$

Most, if not all, implied warranties apply as a matter of law by reason of the Marine Insurance Act $1906,{ }^{77}$ unless they are inconsistent

\footnotetext{
${ }^{75}$ Consultation Paper No. 204, para. 12.2.

${ }^{76}$ See e.g. Blackhurst v Cockell (1789) 3 TR 360.

${ }^{77}$ Sect. 39 (seaworthiness) and 41 (legality).
} 
with the terms of the contract, ${ }^{78}$ or with an express warranty. ${ }^{79}$ It is conceivable, although unlikely, that there may be a warranty implied by reason of the parties' agreement (i.e. by which the intention to warrant is inferred). ${ }^{80}$. It is to be noted that under section 35(3), 'An express warranty does not exclude an implied warranty, unless it be inconsistent therewith.'

Under section 33(3) of the Marine Insurance Act 1906, a promissory 'warranty, as above defined, is a condition which must be exactly complied with, whether it be material to the risk or not.' As will be observed below, however, the materiality of the warranty to the risk has become a hallmark feature of a true promissory warranty. ${ }^{81}$ If there has been any departure from a warranty, no matter how slight (except possibly if the departure is de minimis), there has been a breach of warranty. ${ }^{82}$ The consequences of a breach of a promissory warranty may be summarised as follows (subject to the terms of the warranty or the policy). Immediately upon the breach of warranty, the insurer will be discharged automatically from liability as from the date of the breach, whether or not the insurer is aware of the breach, and the insurer remains liable for any losses incurred by him before the date of the breach of warranty. ${ }^{83}$ The fact that the breach of warranty ceases or is remedied after the initial breach does not result in the insurer coming on risk again. ${ }^{84}$ The breach need have no causative connection with any loss which is the subject of a claim under the contract or with the risk being insured. $^{85}$

\footnotetext{
${ }^{78}$ Sect. 87.

${ }^{79}$ Sect. 35(3).

${ }^{80}$ Sect. 33(2).

${ }^{81}$ HIH Casualty and General Insurance Ltd v New Hampshire Insurance Co [2001] EWCA Civ 735; [2001] 2 Lloyd's Rep 161.

${ }^{82}$ De Hahn v Hartley (1786) 1 TR 343; Union Insurance Society of Canton v George Wills \& Co [1916] AC 281; Sugar Hut Group Ltd v Great Lakes Reinsurance (UK) plc [2010] EWHC 2636 (Comm); [2011] Lloyd's Rep IR 198, [44].

${ }^{83}$ Sect. 33(3); Bank of Nova Scotia v Hellenic War Risks Association (Bermuda) Ltd (The Good Luck) [1992] 1 AC 233; The Buana Dua [2011] EWHC 2413 (Comm); [2011] 2 Lloyd's Rep 655, [38]-[41].

${ }^{84}$ Sect. 34(2).

${ }^{85}$ De Hahn v Hartley (1786) 1 TR 343; Foley $v$ Tabor (1861) 2 F\&F 663; Forsikringsaktieselskapet Vesta v Butcher [1989] AC 852.
} 
Because of these consequences, the Courts have found ways of ameliorating the effect of promissory warranties. First, the Courts will construe any ambiguities in the wording of a warranty or any other term, such as conditions precedent, on which the insurer seeks to rely in order to reduce or extinguish its liability, strictly against the insurer. ${ }^{86}$ Secondly, the Courts have tended to construe terms described as warranties as suspensive or descriptive warranties where the term is less important or fundamental to the risk being insured. If the provision relates to the very essence of the risk or goes to the root of the transaction, it is more likely to be a promissory warranty. ${ }^{87}$ If, for example, the failure to comply with the provision would mean that the risk being insured has increased, even after the breach ceases, it is more likely that the provision is a promissory warranty. ${ }^{88}$ If the warranty is construed as a suspensive or descriptive provision, there will be no cover under the policy whilst the breach remains in existence but once the breach is remedied, the cover afforded by the policy will be reinstated.

The Marine Insurance Act 1906 identifies 3 defences to an allegation of breach of warranty: (1) Non-compliance with a warranty is excused when, by reason of a change of circumstances, the warranty ceases to be applicable to the circumstances of the contract; ${ }^{89}$ (2) Noncompliance with a warranty is excused when compliance with the

${ }^{86}$ The Zeus V [2000] 2 Lloyd's Rep 587, [30]; George Hunt Cranes Ltd v Scottish Boiler and General Insurance Co Ltd [2001] EWCA Civ 1964; [2002] Lloyd's Rep IR 178; Pratt v Aigaion Insurance Company SA [2008] EWCA Civ 1314; [2009] 1 Lloyd's Rep 225.

${ }^{87}$ Barnard v Faber [1893] 1 QB 340; Beauchamp v National Mutual Indemnity Ins Co Ltd (1937) 57 Ll L Rep 272, 275; The Bamcell II [1986] 2 Lloyd's Rep 528 (Sup Ct Canada); Svenska Handelsbanken v Sun Alliance and London Insurance plc [1996] 1 Lloyd's Rep 519, 551-553; Sugar Hut Group Ltd v Great Lakes Reinsurance (UK) plc [2010] EWHC 2636 (Comm); [2011] Lloyd's Rep IR 198, [40]-[54].

${ }^{88}$ De Maurier (Jewels) Ltd v Bastion Insurance Co Ltd [1967] 2 Lloyd's Rep 550, 558-559.

${ }^{89}$ Sect. 34(1); cf. Agapitos Laiki Bank (Hellas) SA v Agnew (No 2) [2002] EWHC 1558 (Comm); [2003] Lloyd's Rep IR 54, [59]; Sugar Hut Group Ltd v Great Lakes Reinsurance (UK) plc [2010] EWHC 2636 (Comm); [2011] Lloyd's Rep IR 198, [42]. 
warranty is rendered unlawful by any subsequent law; ${ }^{90}$ (3) A breach of warranty may be waived by the insurer. ${ }^{91}$ The Courts have held that a breach of warranty may be waived by the insurer only by promissory estoppel and not by election, ${ }^{92}$ even though there was no doctrine of promissory estoppel when the Marine Insurance Act 1906 was passed and even though other references to waiver in the Act (sections 18(3)(b) and 62(8)) have not been so construed.

\section{The Law Commission's Proposals}

The effect of warranties has attracted a great deal of criticism, ${ }^{93}$ in that they can operate harshly. ${ }^{94}$ Against the background of such criticism, the Law Commission proposes that: ${ }^{95}$

1. All warranties operate as suspensive warranties in that any breach will result in the insurer's liability being suspended only whilst the breach remains unremedied.

2. Where the warranty is designed to reduce the risk of a particular loss, a breach of the warranty suspends the insurer's liability only in respect of that type of loss.

3. Warranties of existing facts should be abolished.

4. The parties cannot contract out of the statutory regime at all in respect of consumer insurance and the parties can contract out of the statutory regime in respect of business insurance only if the

\footnotetext{
${ }^{90}$ Sect 34(1).

${ }^{91}$ Sect. 34(3).

${ }^{92}$ Brownsville Holdings Ltd v Adamjee Insurance Co Ltd (The Milasan) [2000] 2 Lloyd's Rep 458, 467; HIH Casualty and General Insurance Ltd v Axa Corporate Solutions [2002] Lloyd's Rep IR 325; aff'd [2002] EWCA Civ 1253; [2003] Lloyd's Rep IR 1.

93 Andrew Longmore, 'Good faith and breach of warranty: are we moving forwards or backwards?' [2004] LMCLQ 158, 164; Malcolm Clarke, 'Insurance Warranties: The Absolute End?' [2007] LMCLQ 474.

${ }^{94}$ Kler Knitwear Ltd v Lombard General Insurance Co Ltd [2000] Lloyd's Rep IR 47, 49.

${ }^{95}$ Consultation Paper No. 204, para. 15.1, 15.9-15.13, 15.14-15.17, 15.26-15.29, $15.35-15.39,15.54-15.59$.
} 
warranty is written in clear, unambiguous language and is specifically brought to the attention of the other party when the contract is concluded.

5. The defences to a breach of warranty set out in sections 34(1) and (3) of the Marine Insurance Act 1906 should be retained.

There is much to be said for the view that true promissory warranties which can operate so powerfully must be evidenced by clear and unambiguous language and that they be specifically highlighted rather than hidden amongst standard terms. Furthermore, as insurance warranties can have devastating consequences for a consumer assured, the Law Commission's proposals have much to commend them.

The position with respect to business insurance is more difficult. One must recall that many business assureds are themselves sophisticated companies operating on the basis of standard terms which are incorporated into their contracts. Furthermore, many business assureds will benefit from the advice of professional insurance brokers.

Promissory warranties can serve an important function in that the insurer agrees to bear a risk of loss which would ordinarily be borne by the assured but only on condition that the assured takes steps which are aimed at fundamentally affecting the risk which the insurer is assuming. The proposals put forward by the Law Commission will operate fairly in many cases, but there are two particular cases where they may provide insufficient protection to the insurer.

First, the insurer may be prejudiced where the breach of warranty has a continuing effect even after it has been remedied. For example, the assured may warrant that the insured vessel will not call into a specific blacklisted port. Of course while the vessel is at the blacklisted port, the cover will be suspended according to the Law Commission's proposals. However, once the vessel leaves the port and the breach is remedied, the cover is reinstated. This may operate unfairly to the insurer where the character or degree of the risk changes as a result of the breach, even after the breach ceases. Taking the example, after the ship leaves the blacklisted port, the risks of an attack on the vessel may increase because the ship will itself be tainted by the blacklist. 
Second, the insurer may be prejudiced where the breach of warranty has facilitated the consequent loss, even though when the loss occurs the breach has been remedied. This has been highlighted recently in piracy cases. In many insurance policies, the assured is subject to a warranty to take self-protective measures to reduce the risk of a piratical attack (such as operating the insured vessel at a minimum high speed or avoiding certain areas). If, therefore, a ship breaches the warranty by proceeding too slowly or by entering an excluded zone, that breach may have allowed pirates to attack and board the insured vessel, even though at the time of the attack, the breach has been remedied.

The Law Commission's recommendation to abolish existing fact warranties, namely warranties by which a state of affairs is warranted to exist or not to exist, is slightly puzzling in that the Law Commission's proposals suggests that existing fact warranties operate more harshly than future or continuing warranties, that is warranties which impose a future or continuing obligation on the assured. It is puzzling because the assured is in a much better position to check the accuracy of the warranted statement and to avoid a breach than in dealing with compliance with future and continuing obligations. Certainly, there was a time when continuing warranties were regarded as operating more harshly. ${ }^{96}$ Furthermore, many commercial contracts are often expressed to be conditional on the truth of warranted statements. It is difficult to understand why a warranted statement of an existing fact is so objectionable. The real objection is the fact that a certain species of an existing fact warranty - the 'basis' clause - is introduced into the contract of insurance by insidious means. Such provisions render a statement of existing fact as a warranty by means only of a provision that the statement forms the 'basis' of or is incorporated into the contract of

\footnotetext{
${ }^{96}$ Thomson $v$ Weems (1884) 9 App Cas 671, 684; Yorkshire Insurance Company Limited v Campbell [1917] AC 218, 224; Hussain v Brown [1996] 1 Lloyd's Rep 627; Kler Knitwear Ltd v Lombard General Insurance Co Ltd [2000] Lloyd's Rep IR 47. Cf. Cornhill Insurance plc v DE Stamp Felt Roofing Contractors Ltd [2002] EWCA Civ 395; [2002] Lloyd's Rep IR 648, [20]; The Game Boy [2004] EWHC 15 (Comm); [2004] 1 Lloyd's Rep 238, [137]-[139].
} 
insurance. ${ }^{97}$ If, however, there is a requirement introduced by legislation that such provisions should operate as warranties only upon the clearest and most unambiguous language specifically highlighted in the contract, this objection evaporates.

The Law Commission's proposals do not necessarily touch these concerns and should do so before the law is altered. ${ }^{98}$ That said, the contracting-out mechanism proposed by the Law Commission may well provide an adequate solution to this issue.

\section{E. Conclusion}

For the past 250 years, English insurance law has developed arguments, commentary, and judgments which make up the common law. There is much in the law concerning the duty of utmost good faith which requires maintenance. Such maintenance does not mean that the law need to be replaced. It means those areas which are productive of the greatest injustice must be changed and those areas of the law which serve a commercial purpose should be retained. The most pressing issue relating to the duty of utmost good faith is not the existence or content of the duty itself, but the remedies for the breach of such a duty.

As the duty of utmost good faith is a reciprocal duty, binding on both the insurer and the assured alike, it would be unwise to reform the law insofar as it bears on the assured's pre-contractual duty of disclosure without regard to the consequences of a breach of the insurer's own duty of disclosure. In the short term, greater flexibility in the grant of remedies for a breach which can take account of the seriousness of the breach or the consequences of the breach and the blameworthiness of the assured's (and the insurer's) conduct are matters which should be taken into account in providing a remedy. This will inevitably involve the use of a judicial discretion, matching that which the Courts may exercise in the

${ }^{97}$ Thomson $v$ Weems (1884) 9 App Cas 671; Dawsons v Bonnin [1922] 2 AC 413; Kumar v AGF Insurance Ltd [1999] Lloyd's Rep IR 147; Zeller v British Caymanian Insurance Co Ltd [2008] UKPC 4; [2008] Lloyd's Rep IR 545.

98 The proposals are also put forward to apply to the implied warranties of seaworthiness and legality under the Marine Insurance Act 1906: Consultation Paper No. 204, para. 16.11-16.18. 
context of non-fraudulent misrepresentations made by a contracting party to another contracting party under the Misrepresentation Act 1967.

Any approach to the law concerning insurance warranties must be similarly circumspect. The harshness of a breach of warranty often ignores the fact that the true promissory warranty performs a vital function as far as the insurer is concerned and often the insurance protection offered by an insurance policy is conditional on such warranties being observed by the assured. To restrict the scope of such warranties does interfere with the parties' contractual freedom. That is not to say that such warranties cannot benefit from legislation requiring warranties to be expressed in clear and unambiguous terms, to be brought specifically to the attention of the assured, and to be construed as suspensive provisions if they are in reality not of fundamental importance to the risk being insured. In such cases, the law should adopt a strict approach to promissory warranties, but the common law appears to have developed to that end in any event.

Law reform is a critical feature of the just and rational development of any body of law, not least the English law of insurance. Reformist passion however must be constrained to provide assistance only where the Courts are unwilling or unable to act to evolve the common law to achieve such just and rational objectives. 